\title{
Broker use and the cost of liquidity in commercial real estate investment
}

Article

Accepted Version

Devaney, S. and Scofield, D. (2013) Broker use and the cost of liquidity in commercial real estate investment. Journal of European Real Estate Research, 6 (3). pp. 279-302. ISSN 1753-9269 doi: https://doi.org/10.1108/JERER-06-2013-0010 Available at https://centaur.reading.ac.uk/34420/

It is advisable to refer to the publisher's version if you intend to cite from the work. See Guidance on citing.

To link to this article DOI: http://dx.doi.org/10.1108/JERER-06-2013-0010

Publisher: Emerald

All outputs in CentAUR are protected by Intellectual Property Rights law, including copyright law. Copyright and IPR is retained by the creators or other copyright holders. Terms and conditions for use of this material are defined in the End User Agreement.

\section{www.reading.ac.uk/centaur}

\section{CentAUR}

Central Archive at the University of Reading

Reading's research outputs online 


\section{Broker Use and the Cost of Liquidity in Commercial Real Estate Investment: Analysis of Transaction Data for London and New York}

Steven Devaney ${ }^{1}$ and David Scofield ${ }^{2}$

${ }^{1}$ Real Estate \& Planning, Henley Business School, University of Reading, Whiteknights, Reading, RG6 6UD

United Kingdom

${ }^{2}$ University of Aberdeen Business School, Edward Wright Building,

Dunbar Street, Aberdeen, AB24 3QY

United Kingdom

Published in 2013 in the Journal of European Real Estate Research, Vol. 6, Issue 3, Pages 279-302.

DOI: 10.1108/JERER-06-2013-0010

\section{Acknowledgements}

The authors would like to thank Real Capital Analytics for the provision of data on which the empirical analysis has been based and participants at the 2012 Meeting of the European Real Estate Society for comments on an earlier version. The views expressed and any mistakes or omissions are the responsibility of the authors alone. 


\begin{abstract}
Purpose - Commercial real estate is a highly specific asset: heterogeneous, indivisible and with less information transparency than most other commonly held investment assets. These attributes encourage the use of intermediaries during asset acquisition and disposal. However, there are few attempts to explain the use of different brokerage models (with differing costs) in different markets. This study aims to address this gap.
\end{abstract}

Design/methodology/approach - The study analyses 9,338 real estate transactions in London and New York City from 2001 to 2011. Data are provided by Real Capital Analytics and cover over $\$ 450$ billion of investments in this period. Brokerage trends in the two cities are compared and probit regressions are used to test whether the decision to transact with broker representation varies with investor or asset characteristics.

Findings - Results indicate greater use of brokerage in London, especially by purchasers. This persists when data are disaggregated by sector, time or investor type, pointing to the role of local market culture and institutions in shaping brokerage models and transaction costs. Within each city, the nature of the investors involved seems to be a more significant influence on broker use than the characteristics of the assets being traded.

Originality/value - Brokerage costs are the single largest non-tax charge to an investor when trading commercial real estate, yet there is little research in this area. This study examines the role of brokers and provides empirical evidence on factors that influence the use and mode of brokerage in two major investment destinations. 


\section{INTRODUCTION}

Commercial real estate can be an attractive investment option, with the best assets providing a stable, long-term income return coupled with the possibility of increases in capital value. In a portfolio context, returns from real estate provide diversification benefits, under certain conditions, when compared with returns from equities and bonds. ${ }^{1}$ Furthermore, the private real estate market offers opportunities to actively manage assets and so influence their income generating potential. However, investors encounter high transaction costs in private real estate markets because of the dispersed and private nature of these markets and the heterogeneous nature of the assets, which exhibit widely varying physical and locational characteristics. These factors increase search and information costs as well as the complexity of a transaction once a suitable investment has been identified.

The attributes of real estate assets ensure that the transaction process is costly and time consuming, with the risks and costs being of a character and order that is different from other mainstream investment assets. For instance, within this process, price agreement - the moment a bid meets or exceeds a seller's minimum reservation price - is only the beginning of further negotiations and processes that are neither immediate nor without friction. Lin and Vandell (2007) explore risks related to liquidity, such as the uncertainty of marketing/selling periods and the difficulty of liquidating assets rapidly in response to shocks. Meanwhile, Bond et al. (2007) note risk mitigation strategies that investors may adopt in response, such as longer holding periods and a minimum number of assets to be held in a portfolio.

\footnotetext{
${ }^{1}$ For recent evidence, see MacKinnon and Al Zaman (2009) or Rehring (2012). (http://centaur.reading.ac.uk/). Emerald does not grant permission for this article to be further copied/distributed or hosted elsewhere without the express permission from Emerald Group Publishing Limited.
} 
The high costs and extended time taken to transact real estate, with a high degree of information asymmetry between seller and buyer, culminate to negatively affect the liquidity of the asset. This is important as the less liquid an asset, the higher the inherent risk of holding it (Grossman and Miller, 1988; Bond et al. 2007). Market and asset information necessary to overcome inherent asymmetries and reduce transaction risk often comes through intermediaries (brokers/agents) who work between and on behalf of investment firms. However, intermediaries can represent a substantial transaction cost. Considered as a percentage of the price of the asset, the cost of the broker or agent is often the greatest nontax charge to the investor, at around $1 \%$ of the price of the asset (McAllister et al., 2008).

Research by McAllister et al. (2008) and Sawyer et al. (2003) highlights the importance of brokers and the process of brokerage to understanding these issues. However, while research has identified liquidity variation as a key by-product of the transaction process, it offers little direct analysis of the role of brokers in commercial real estate markets or the transaction costs specifically associated with brokerage and how these might be usefully defined as explicit liquidity costs. There are no extant studies that consider the costs of liquidity as directly related to local institutions and the attendant cost of brokerage; nor are there academic studies to our knowledge that consider how these costs vary across commercial real estate markets. This paper marks the first time that explicit costs of transacting (acquiring) commercial real estate have been equated to liquidity costs influenced by different institutional environments in which exchange occurs. We consider the costs of liquidity to be a function of broker representation since successful investment into commercial real estate requires timely asset and market knowledge that is often provided by brokers/agents working outside the investment firm. These are specific, measurable costs of liquidity that are influenced by institutions and which vary according to differences in observable brokerage use and (http://centaur.reading.ac.uk/). Emerald does not grant permission for this article to be further copied/distributed or hosted elsewhere without the express permission from Emerald Group Publishing Limited. 
structure. The cost to the investor of securing necessary knowledge through brokers prior to and during the acquisition or disposal of real estate is a key transaction cost.

This paper examines how both broker use (whether a transaction involves a broker or not) and broker structure (whether one or both parties are represented or not) varies both across and within different commercial real estate markets. Such variations may be expected where there are differences in the complexity of assets or the nature of the parties to the transaction. In the latter case, if some participants are more active than others in a particular real estate market, then these actors may have less need of the search and information functions that brokers provide. On the other hand, for sellers, the marketing function of brokers may remain important. While these arguments seem logical, it is not known to what extent they correspond with the actual use of brokerage by different market participants. It is this question that this paper sets out to answer.

The study uses transaction data from London and New York City, which were selected owing to their importance as destinations for international real estate investment and so that crossborder comparisons could be made. ${ }^{2}$ Marked differences are found between these two cities in terms of the prevalence of brokerage, with London exhibiting much greater levels of buyer representation and of double (or differentiated) brokerage. This does not simply reflect differences between these locations in the mix of assets and investors, though asset and investor characteristics play some role in explaining which deals within a market are likely to be brokered. Instead, differences persist across property types, time and investor groups, suggesting that local institutions and investment culture strongly influence the approach to

\footnotetext{
${ }^{2}$ Newell et al. (2010) document how New York and London were the top two cities globally in terms of commercial real estate capital flows prior to and just after the onset of the global financial crisis. These cities are also the primary financial centres within their respective time zones.
} 
brokerage that is adopted in different locations. This, in turn, influences transaction costs in those places.

The next section discusses prior research on brokerage that is related to this investigation. After this, the dataset used to examine brokerage patterns is presented and explored through tabular analyses. Results from probit models that more formally test which factors explain the form of brokerage observed for individual deals are then discussed. A final section concludes by examining the findings of the study in the light of ideas from institutional economics.

\section{BROKERAGE}

The nature of commercial real estate assets affects the structure of the market through which they are exchanged and informs investment processes both within the investment firm and across the wider market. Asset attributes affect transaction time whilst the transaction period, though variable, incurs costs that are observable and relate to the role of brokers/agents in the exchange process (Malone and Smith, 1988). Market structures and processes are driven by human action (Mises, 1949; Hayek, 1945) and incur unique costs. Networks of brokers/agents frequently facilitate the exchange of commercial real estate assets and this introduces costs unique to real estate investment (Williamson, 1991; Burt and Knez, 1995).

The role of the broker can be further defined as facilitating liquidity, at a cost. The cost incurred in performing this function relates to facilitating communication between seller and buyer, introducing asset specific knowledge to the investor necessary to initiate a transaction, and addressing other risks during the exchange, all defined here as the costs of liquidity. For 
investors, the decision to acquire strategically important investment knowledge through brokers is a product of firm level calculations (Williamson, 1979; Klein, 1996; Alchian and Demsetz, 1972). These calculations drive internal decision making concerning the investment process and determine the market and firm boundaries that then define and determine specific brokerage structures (Zenger et al., 2011). The cost of the broker is the price of knowledge pivotal to the successful acquisition of real estate assets. Firm level capital calculations and attendant costs are dynamic and will vary across markets. As the costs of brokerage vary, so too will the costs of liquidity.

Research concerning intermediation and broker effects is heavily geared toward residential real estate and no extant studies define the role of the broker as that of providing liquidity, nor the price of the broker and the cost of the transaction as an explicit liquidity cost. There is comparatively little research available regarding intermediation and brokerage in commercial real estate markets. Hence, the following brief review of literature on residential brokerage is designed to provide context for discussion of the much more limited number of studies that address brokerage in commercial real estate. A more comprehensive survey of the residential literature can be found in Zietz and Sirmans (2011).

Yinger (1981) creates a model of matching behaviour in which brokers seek to affect individual asset (house) prices, but not the distribution of prices across the market. Salant (1991) then examines broker effects on residential asking prices and models optimal sale prices based on the inclusion of a broker at different phases of the sale. The author notes the potential affect of broker commissions in dissuading sellers from engaging the services of a broker when initially listing their property. Meanwhile, Jud (1983) concludes from a limited study of urban areas in North Carolina that brokers (generally) do not affect the price of (http://centaur.reading.ac.uk/). Emerald does not grant permission for this article to be further copied/distributed or hosted elsewhere without the express permission from Emerald Group Publishing Limited. 
houses they sell. However, Jud and Frew (1986) conclude that brokers do affect house prices, obtaining higher prices in comparison to sellers marketing their homes without the aid of broker representation. This, the authors conclude, is analogous to an advertising effect in markets with imperfect information.

Rutherford et al. (2005) provide perhaps the most quoted study (cf. Freakonomics) into brokerage effects on transaction cost and price. They found that agent owned properties sell at a premium (4.5\%-7.0\%) above non-agent owned properties as agents kept their own properties listed for longer in order to seek higher prices; an example of misaligned incentives as the marginal return for the additional time to seek a higher price is less significant when the agent is selling for another. Information asymmetry and misaligned incentives in broker contracts has also been explored by Anglin and Arnott (1991). They found that the typical fixed commission contract between agents and principals failed to fully address inherent information asymmetries, or to allocate risk and efficiently align incentives of the agents involved (see also Yavas and Colwell, 1999). Bajtelsmit and Worzala (1997) examine the problems associated with information asymmetry around the use of sub-agents (broker working with seller broker, or listing agent) and dual agency (two brokers, both belonging to the same firm). They observe that when home buyers believe that a sub-agent is working on their behalf (instead of with and on behalf of the seller's agent), the result is higher selling prices at the expense of the buyer. Conversely, when sub-agent arrangements were disclosed, the result was lower sales prices, ceteris paribus. 
Separate buyer brokerage became a common form of broker representation in the United States in response to disclosure laws enacted in $1993 .{ }^{3}$ It is distinct from either sub-agency or dual agency, as only this route offers a buyer specific representation that is independent from that of the seller. However, it is possible that different offices of the same brokerage firm can act with a degree of autonomy. For example, as commercial real estate markets have become more international, it is not unusual for buyers and sellers of investment grade real estate to be represented by different offices of the same brokerage firm, with the buyer broker based in the same country as the buyer. To our knowledge, the incentives for and behaviour of brokers in this context has yet to be researched.

Zumpano et al. (1996) consider broker use among buyers of homes across the United States. They found that when buyers face high opportunity costs and lack local market knowledge, broker use is more likely. In addition, brokers were found to be associated with lower search times and reduced search costs, but did not have a significant effect on selling prices once selection bias was controlled for. Elder et al. (2000) in a subsequent study consulted data on 10,000 home purchases, categorizing each transaction as brokered or not; buyer broker or not; and if brokered, how the buyer broker was compensated. They note that the buyer broker in the residential sales context is costless to the buyer as the buyer broker commission is shared from proceeds of the total sales commission. This is in contrast to the typical situation in commercial real estate where brokers are paid directly by the party they represent. More recently, Wiley et al. (2012) examine how buyer characteristics vary with different forms of brokerage. Their work finds that certain buyers (low-income, non-native English speakers) are significantly less likely to complete an acquisition with broker representation.

\footnotetext{
${ }^{3}$ This legislation required the listing agent, or seller's broker, to disclose the nature of any sub-agency or dual agency explicitly. 
Discussion of the issues around brokerage (search, time on market, price effect and principalagent alignment) is far less developed in the commercial real estate field. A noteworthy exception is McAllister et al. (2008) that considers buyer broker effects on property selection by UK institutional investors. This work applies agency theory in unpacking the roles of the broker and the effect of information asymmetry within the commercial real estate investment process. The authors identify the system of agency in the UK as one in which buyers and sellers typically retain independent broker representation: a system of double, or differentiated, brokerage. They find that the principals involved in commercial real estate tend to be experienced, sophisticated investors who have a better understanding of the asymmetries and incentives that can affect agent behaviour, in contrast to typical owneroccupiers operating in the residential market. The authors argue that this, together with the desire of agents to secure repeat business, serves to limit opportunistic behaviour by buyer brokers.

There are scarcely any studies that explicitly consider the role of the broker in terms of transaction cost and price in commercial real estate investment because of the paucity of relevant available information. An exception to this is research by Graff and Webb (1997) that questions the relationship between asset price and brokerage cost and identifies misaligned incentives between principals and agents. They isolate and discuss subjective aspects in the appraisal of value for commercial real estate and reference the importance of private information in the commercial real estate market. They model exceptional agency costs as a product of information asymmetries and exceptional price discovery costs unique to commercial real estate investment. The work concludes that agency costs are a source of 
economic inefficiency, with the poor performance of US offices a consequence of excessive agency costs.

More recently, Hardin et al. (2009) analyse the effects of brokerage on transaction prices in the condominium markets of Phoenix and Atlanta. They conclude that, in these small commercial markets characterized by few investors and transparent assets, the broker had no significant effect on transaction price. The authors suggest that this is probably a consequence of the market sophistication of the investors involved in these commercial transactions, coupled with high levels of transparency concerning the income attributes of the properties in the study.

The question that has not been addressed in the literature to date is what factors affect the use and structure of brokerage in commercial property transactions. The following section confirms that the commercial real estate investment process in London and New York City commonly includes some form of brokerage; however, the use of a buyer broker varies significantly between the two markets. This finding has further significance as buyer broker representation represents a direct cost of approximately $1 \%$ of the price of the real estate asset to the buyer. Put another way, the boundaries of commercial real estate investment firms active in London and New York City are not congruent; there is significant variation in the way real estate investors acquire the knowledge necessary to facilitate investment.

The variations observed are evidence of institutional differences, differences in the rules of the game, in norms and codes of practice that coordinate interactions and govern relations between individuals (Davis and North, 1971). From the perspective of new institutional economics (Coase, 1960; 1964), and more specifically comparative institutional analysis (cf. 
transaction cost economics) (Williamson, 2008), the system and structures observed in these market transactions should provide the optimum governance trade-off for both buyer and seller ${ }^{4}$, ceteris paribus. When a buyer is represented separately from the seller, transaction and liquidity costs increase. Nonetheless, transaction cost economics maintains that the system of exchange employed (no broker, one broker or two brokers) should be the one that the parties perceive best balances costs and risk. Given the relative strength of the investment players in this market - among both institutions and brokers - the possibility of persistent oligopoly seems unlikely. Rather, it seems more likely that the system of intermediation employed provides a service (e.g., greater anonymity and market reach) that investors consider to be more valuable than the cost of brokerage. Liquidity comes at a cost reflected in the price of brokerage.

\section{DATASET AND RESULTS}

To explore these ideas further, data on real estate transactions in London and New York City are examined. These locations were selected for study owing to their size, depth and importance as real estate markets in their respective countries and the international investment arena. Furthermore, anecdotally, they exhibit different forms of and approaches to brokerage, something that this analysis confirms. Transaction data was supplied by Real Capital Analytics (RCA), a research organization that collects and analyses data on real estate investment transactions in all major real estate markets across the globe. RCA focus on transactions of $\$ 2.5$ million or greater in the US and \$10 million or greater elsewhere; in the

\footnotetext{
${ }^{4}$ Coase (1964) and Williamson (1979) note that comparisons of market organization must occur between systems that exist, not theoretical typologies. 
case of London, many deals below the $\$ 10$ million threshold have been recorded. RCA works in partnership with Property Data (UK), which is the primary source for the London data. Information on each transaction is gathered from multiple sources, where possible, including subscribing brokerage and investment firms, listing services, press reports and other public records. RCA approximate their coverage to be $95 \%$ of all real estate transactions over these thresholds for the locations studied here.

The dataset spans the period Q1 2001 to Q4 2011 and comprises transactions of both single assets and portfolios of assets. The analysis here focuses on deals involving single assets, of which there were 10,687 in the two cities over the period concerned. ${ }^{5}$ The number of transactions varies over time as market conditions change and this is exhibited in Figure 1. Three broad phases can be identified; a period of muted growth and/or low transaction activity (2001-2004), a period of strong growth and high transaction volumes (2005-2007) and, finally, a strong market correction starting mid- to end-2007 that is accompanied by a fall in the number of deals.

\section{INSERT FIGURE 1 ABOUT HERE}

The dataset consists of deals for different property types in different districts within each metro area. For example, the New York data contains transactions both for Manhattan and the outer boroughs, and deals that relate to income-producing apartment blocks as well as offices, hotels, retail and industrial properties. London, in comparison, has only a handful of apartment deals, reflecting the different structure of the investment market, but transactions in

\footnotetext{
${ }^{5}$ Note that an 'asset' such as an industrial estate or office park may itself comprise more than one building. 
both central and outer London are included. All property types are studied below, but development sites were excluded from the analysis. These accounted for 554 transactions, just over $5 \%$ of the total by number.

Transaction prices were supplied in US dollars and Pounds Sterling in all cases. Each city is analysed separately and, where prices are used either for weighting purposes or to distinguish high from low value assets, local currency figures are used to prevent distortions from currency fluctuations over the period studied. Prices were deflated into real terms using the relevant national CPI index and recorded transaction month in each case, with December 2000 used as the base point. ${ }^{6}$ This was so that the price and price per unit of an asset could be compared with that of other assets trading at different times, though analyses using nominal prices produce results that are qualitatively similar to those that follow.

Aside from price, date, sector and location, the dataset includes the following fields; address, floorspace or number of units, nature of the legal interest, buyer type and national origin, seller type and national origin, and the identity of any brokers used by each party. Capitalisation rate is available in some cases, but coverage is partial, as is also the case for some physical attributes such construction date and the number of floors. Observations were removed from the dataset if they contained no information on either the type of buyer or type of seller, as these aspects are central to the analyses that follow. This affected 795 cases, leaving a final sample of 9,338 transactions or $87.4 \%$ of the original number of deals available.

\footnotetext{
${ }^{6}$ The US CPI series used was the national index for All Urban Consumers (All Items) available from the Bureau of Labor Statistics. The UK CPI series (All Items) was sourced from the Office for National Statistics.
} 
To explore the forms of brokerage used and the circumstances in which different forms occur, a variable was created with the following categories: 1) No broker, 2) For seller only, 3) For buyer only and 4) Broker for both parties. If broker identity is not recorded, it is assumed that no broker was used by that party, although it is possible that the information is simply missing. ${ }^{7}$ The categories facilitate econometric analysis of what distinguishes transactions where brokerage is observed and cases where each party is represented by a broker. First, though, tabular analyses are presented that show the proportion of deals by number and/or value that fall into each group.

In addition, variables indicating whether the buyer or seller was domestic or foreign were generated under the assumption that non-domestic investors may require the professional and information services offered by brokers to a greater extent. However, this was complicated by two factors. First, the evolution of property investment vehicles and the internationalization of real estate investment mean that, while the registered office of an owner may be easy to identify, the location of the effective or beneficial ownership may be very different and difficult to observe, as well as spread across multiple parties. ${ }^{8}$ Second, the use of joint ventures means that more than one buyer or seller may be recorded, with both domestic and non-domestic parties present. In regard to the first issue, the study simply uses RCA's categorisations with respect to nationality of ownership. For the second issue, the investor variables were refined to indicate cases with partial domestic involvement as well as cases where nationality was unknown.

\footnotetext{
7 Unless confidentiality clauses restrict such disclosure, brokers are incentivised to identify themselves as RCA publish broker rankings amongst their other outputs.

${ }^{8}$ See Lizieri and Kutsch (2006) for extended discussion of this issue in the context of London. 
Table 1 shows aggregate information on the use of brokerage in London and New York City. In this period, $\$ 457 \mathrm{bn}$ was transacted in nominal terms and just over $\$ 400 \mathrm{bn}$ once prices are adjusted for inflation. There are more observations for New York, but, if the apartment sector is excluded, the number of transactions for each city is roughly equal. Each transaction has been classified into one of the four brokerage categories and, by adding together relevant categories, the total extent of seller representation and buyer representation is reported. ${ }^{9}$ The table shows a clear difference between the two cities in terms of broker use. Both buyer and seller representation are higher in London and the difference is especially notable in the case of buyers, being $63 \%$ of transactions in the case of London versus only $9 \%$ for New York.

\section{INSERT TABLE 1 ABOUT HERE}

The higher level of buyer representation in London means that there are more instances where two brokerage firms are involved in the transaction, one on behalf of the buyer and another for the seller. However, in a small number of cases (23 out of 1,754 deals), a single firm is recorded as having acted for both parties. In New York City, there are fewer instances where both parties are represented, but more cases where the same firm acts for both sides. Out of 490 transactions where both parties use brokerage, 280 are instances where a single firm acts for buyer and seller. As per the earlier discussion, some of these cases may be instances of dual agency in the traditional sense, but others may reflect representation of each party by different national offices of globalised real estate service providers.

\footnotetext{
${ }^{9}$ For instance, 'Buyer represented' contains the sum of values shown in the columns 'For buyer only' and 'Broker for both'. 
Some of the patterns at city level could simply reflect that a different mix of assets is traded in each market. For instance, in New York, the apartment sector is much more important as an investment option than in London. Therefore, Table 2 splits the sample by sector within each city to explore whether differences are a function of property type. The results for New York City show that offices are brokered more often than assets in other sectors, but still to a lesser extent than assets in London, especially in respect of buyer brokerage. For London, the retail, office and industrial sectors exhibit similar levels of brokerage and have been more frequently brokered than the remaining property types.

\section{INSERT TABLE 2 ABOUT HERE}

Within each sector, there may be differences in brokerage patterns according to the quality of the assets transacted. In this dataset, there are no direct measures of building or tenant quality, but the price per unit of floorspace (or per apartment) is used here as a proxy measure ${ }^{10}$ For each city, within each sector, transactions were ranked using the relevant price per unit measure and then divided into four quartiles. This was with the exception of the apartment sector in London and the hotel sector in both cities where sample sizes were too small. The use of brokerage within each quartile was then examined. The results are summarised by Figure 2, which suggests that there is no consistent relationship between broker use and asset quality. Only in the New York retail and apartment sectors does a pattern emerge, with top and upper middle quartile assets (those achieving higher prices per unit) more frequently brokered than those in the lower quartiles. No such patterns exist in the London data.

\footnotetext{
${ }^{10}$ There are 278 cases in London and 25 cases in New York where this information is missing and so the assets concerned are excluded from this particular analysis. 


\section{INSERT FIGURE 2 ABOUT HERE}

In both of the cities, the use and form of brokerage appears to have shifted over time. Whilst buyers and sellers in London are still far more likely to be represented by a broker than in New York, Table 3 indicates a reduction in representation during the period 2005-07 when capital growth in the commercial real estate market was strongest. By contrast, in New York, there appears to be a longer term shift towards increased use of brokers by buyers that began in the stronger market of 2005-07 and continued in the subsequent downturn. As with the results in Table 1, this does not appear to solely reflect changes in the mix or quality of assets being traded.

\section{INSERT TABLE 3 ABOUT HERE}

Another issue is whether the characteristics of the parties involved affect whether brokerage is observed. Certain types of market participant might possess greater market knowledge or engage in transactions more frequently than others; this is likely to be so for financial institutions and publicly listed real estate companies in comparison with corporations or individuals buying or selling as building users. With greater knowledge or experience, it is hypothesised that the need to engage a broker is reduced, especially on the buy side where the marketing element of brokerage is not required. This dimension is considered in Tables 4 and 5, which examine the influence of buyer and seller type or domicile on broker use.

Table 4 focuses on the characteristics of buyers. For London, it can be seen that financial institutions were the group of buyers most often represented and users were the least represented. This seems counter-intuitive given the relative expertise of each group and 
suggests that institutional context or local culture may be important. In contrast, users and joint ventures (with multiple organisations involved on the buy side) were the buyer types most likely to be represented in New York. Meanwhile, domicile appears to have little influence in London on broker use, but the New York results show that foreign buyers were much more likely to be represented by brokers in this period, a result that seems more consistent with likely differences in information or market experience.

\section{INSERT TABLE 4 ABOUT HERE}

Table 5 then reports how often different types of seller were represented in each market. This time, there appear to be few differences across any of the categories in the London case, but the New York figures suggest a strong association between the use of brokers and the Institution and Equity fund seller groups. Again, domicile seems to be of little importance in London, but does appear to be important for New York City, with foreign sellers more often represented by brokers than their domestic counterparts.

\section{INSERT TABLE 5 ABOUT HERE}

The tabular analysis highlights distinctive behaviour with respect to brokerage between London and New York, with a much greater level of brokerage occurring in the former. It also reveals interesting patterns regarding when brokerage occurs within each market, especially with regard to the characteristics of the parties engaging in each deal. However, this style of analysis does not control for factors beyond the specific aspect being studied in each case, so econometric analysis is conducted to test whether some of these patterns remain once other factors are controlled for. 


\section{ECONOMETRIC ANALYSIS}

In this section, probit models are presented that allow the effect of different variables on broker use to be studied while other factors are held constant. Three sets of models are estimated. One set examines the decision by sellers to use brokerage and another set examines the decision to use a broker by buyers. A final set of models then explores the factors that affect the likelihood of brokers being used by both parties. Transaction data for each city is modelled separately with the aim of comparing results and seeing whether similar factors influence brokerage decisions in each case, notwithstanding the clear difference between the cities in broker use overall. The modelling focuses on core commercial (office, retail and industrial) assets in each city, but separate models for the apartments sector in New York are presented as well for comparative purposes.

The dependent variable in each probit model is dichotomous in form. For the first set of models, it takes a value of 1 if a broker is observed as having acted for the seller in the transaction and 0 if no seller broker was observed. A similar dependent variable is then defined for the second set of models, but with the focus here on whether or not a broker acted for the buyer. In the final set of models, the dependent variable takes the value of 1 if brokers for both the buying and selling parties were observed, and 0 if only one or neither of those parties was represented. However, a dilemma arises in respect of cases where the same 
brokerage firm acted for both sides. For the results presented here, these are treated as instances of buyer and double brokerage in the second and final set of models, respectively. ${ }^{11}$

Dummy variables for the year of transaction and sector to which each asset belongs are then used as independent variables, as well as other dummies that attempt to capture the nature of the buyer and seller. Institutional buyer and Institutional seller take the value of 1 where the buying or selling parties, respectively, include a financial institution or equity fund, ${ }^{12}$ while Multiple buyers and Multiple sellers are recorded as 1 if there is more than one party in that role, such as where an asset is being traded by a joint venture. Partial interest indicates that a majority or minority interest in the asset was traded and identification of an asset as either Top quartile or Bottom quartile is based on the quality analysis discussed earlier.

Other indicators denote whether the buyers or the sellers are recorded as being domestic or foreign or whether nationality was unknown. Nationality may be important in determining broker use in that it could indicate familiarity (or otherwise) with the market concerned and the extent of access to local market information. In terms of transactions with multiple buyers or sellers, a dilemma arises if one partner is domestic and the other is not. Here, these cases are defined as 'domestic' on the grounds that the foreign partner will benefit from the local expertise of their domestic counterpart, but the number of such cases is relatively small (see Table 6) and the results that follow are robust to them being classed as either foreign or domestic for the purposes of model estimation.

\footnotetext{
${ }^{11}$ Results from the alternative treatment of excluding them from the buyer brokered and double brokered groups are qualitatively similar and available from the authors on request.

${ }^{12}$ The inclusion of equity funds in a wider definition of institutions follows the practice used by RCA and reflects the high degree of institutional management and involvement in such funds.
} 
Finally, the log of the transaction price was used to detect any tendency for higher value assets to be brokered once other factors were controlled for such as the nature of the parties involved. However, findings from the literature suggest that price may be endogenous to the brokerage decision, i.e. it may be influenced by whether or not the buyer or seller selects a broker to represent them. Therefore, an instrumental variables approach was taken to address this, with the price variable being instrumented in the commercial real estate case by a variable formed from asset floorspace multiplied by mean price per square foot for the sector concerned. In the case of apartments, the instrument used was simply the number of units in the apartment block.

Further information on the dummy variables is given in Table 6. This reports the proportions of the samples for which a given variable takes the value 1 rather than zero. The sample sizes are smaller than those used in the preceding section owing to cases without floorspace or number of units being omitted from the estimations. The cyclical pattern in trading noted from Figure 1 is again evident from the proportions for year dummies while the relative importance of different investor groups in each market is clearer. It can be seen that financial institutions and equity funds are involved in a far greater share of transactions in London than is the case in New York, while foreign buyers and sellers are much more prevalent; proportions for these groups in New York City being very small in both the commercial and apartment sector cases.

\section{INSERT TABLE 6 ABOUT HERE}

Estimated coefficients for the probit regressions concerning seller brokerage are shown in Table 7. Standard errors that are robust to clustering have been used to determine the 
significance of coefficients owing to the likely presence of correlation between the error terms of some observations. This arises because a reasonable proportion of the assets in the sample are traded more than once in the period studied. ${ }^{13}$ If unobserved, asset-specific attributes in such cases contribute to the likelihood of broker use, then these will affect multiple observations in the dataset. Therefore, robust standard errors are used as a precaution.

\section{INSERT TABLE 7 ABOUT HERE}

The results in Table 7 suggest that, from the available information, patterns in seller brokerage are easier to explain in New York than in London. Few of the coefficients in the London model are significant and those which are do not seem to correspond with arguments concerning either asset complexity or information asymmetry. For New York, offices (the base group) were more likely to have had brokerage than other types of commercial real estate and there is a positive coefficient for price in both the commercial and apartment sector models, indicating that brokerage is more likely for assets commanding higher prices. For apartments, the Top quartile coefficient is significant and positive and, for Bottom quartile, it is significant and negative, but a similar pattern is not observed for the commercial sector. It is also interesting that the coefficient for Partial interest is negative for both London and New York, but there are very few such cases and it could reflect instances where trading occurred with other parties holding fractional interests in the same property, perhaps eliminating the need for brokers, though this cannot be confirmed from the available data.

\footnotetext{
${ }^{13} 2,733(29 \%)$ of the 9,338 single asset transactions relate to assets that trade more than once during the period. There are 1,253 such assets compared to 6,605 cases that trade only once between 2001 and 2011.
} 
Coefficients for investor variables indicate that institutional investors were significantly more likely than other types of seller in New York City to use brokers, holding other factors constant. The discrete effect of the seller being an institution on the probability of observing a seller broker is $7 \%$ in the commercial case and $18 \%$ in the apartment case. The corresponding coefficient in the London model is not significant. Meanwhile, it was expected that Multiple sellers would increase the likelihood of brokerage since the involvement of more parties arguably complicates the transaction and increases the need for professional advice. Yet results for both cities do not indicate a significant difference from the single seller case. Foreign domicile has no significant effect either, but this may make sense if these investors already have market knowledge as a result of their current ownership and so make brokerage decisions on similar criteria to their domestic counterparts. As a caveat, though, it should be noted that the unknown group is significant in some instances and the number of cases where domicile of either the buyer or seller is unknown is fairly sizeable. ${ }^{14}$

The coefficients from the buyer brokerage regressions are shown in Table 8. Here, the New York City regressions only use transactions from 2005 onwards. This is because, prior to this date, there are almost no observations of buyer brokerage in the New York data. A similar picture to that of Table 7 is evident. For London, few coefficients are strongly significant, but, in contrast, most of the asset and investor variables are significant in the New York commercial sectors model. In the latter case, offices were more likely to have had buyer brokerage than other property types while, in London, this was the case for retail rather than office assets. Buyers were less likely to use brokers for Bottom quartile assets in both cities and the coefficients on Partial interest echo those found in the seller broker regressions. The impact of price, though, is less consistent.

\footnotetext{
${ }^{14}$ See earlier discussions and the notes for Tables 4 and 5. 


\section{INSERT TABLE 8 ABOUT HERE}

For the investor variables, the coefficients indicate quite different patterns between the two cities. In London, institutional buyers were more likely to use brokers than any other type of buyer, the discrete effect of their involvement being to increase the probability of buyer brokerage by $10 \%$. In New York, though, institutional buyers were less likely to use brokers to represent them in commercial property purchases, their involvement reducing the probability of buyer brokerage by $7 \%$. Furthermore, unlike London, Multiple buyers have a positive effect on buyer brokerage while foreign buyers in New York were more likely than domestic buyers to use a buyer broker (the caveat about the unknown cases remains). The New York findings seem consistent with ideas about transaction complexity and the relative knowledge and experience of different buyer types operating within that market.

Results for the final set of models that examine double brokerage are presented in Table 9. Once again, in the case of New York City, only transactions from 2005 onwards are used. For the London data, double brokerage is as difficult to explain with the available variables as either seller or buyer brokerage alone. None of the asset variables are significant at the 5\% level and few of the investor variables work well. The exception to this is when institutional investors are involved in a deal; they are significantly more likely to be involved in double brokered transactions than non-institutional counterparts. However, the reverse is true for sales of commercial real estate in New York City. Institutional investors here, both as buyers and sellers, are less likely to be involved in transactions where both parties are represented. The results suggests that such investors, who typically are amongst the most professional and 
well informed market participants, perceive these different modes of transacting as offering particular advantages within the institutional environment that exists in each place.

\section{INSERT TABLE 9 ABOUT HERE}

\section{CONCLUSION}

The transfer of commercial real estate assets occurs over an extended period typically lasting weeks or months (see Scofield, 2013) and often involves some form of brokerage. The function of the broker/agent is to provide knowledge of the asset and the counterparty; knowledge that is crucial to the transaction. This function underpins asset liquidity and so the broker can be seen as both a determinant and measurable cost of liquidity. Yet studies of commercial real estate investment commonly investigate liquidity without an explicit focus on brokerage. While some research has helped define and develop the role of brokers/agents within commercial real estate markets (e.g. McAllister et al., 2008), this is the first study, to our knowledge, that shows significant variations in broker use and its associated transaction costs across international real estate investment markets, and to explicitly equate these with variable liquidity costs.

The paper highlights important differences in the use and form of brokerage between the real estate markets of London and New York City. Overall, buyer representation is much higher in London, occurring in $63 \%$ of transactions as compared to only $9 \%$ of cases in New York. Transactions in London are more likely to be brokered and, when brokerage occurs, it is more likely to involve two brokers; one acting for the buyer and one for the seller. These 
differences are not simply a function of the mix of assets and investors in each location, as distinctions remain when comparisons are made between individual sectors or investor types. The findings are significant because a brokered transaction will present higher transaction costs as compared to non-brokered transaction, while transactions involving two distinct brokers represent the highest transaction costs overall.

In the case of London, regression analysis indicates the dominance of investor over asset attributes for explaining whether brokers are used and whether both parties are represented. In New York City, asset attributes play a greater role in predicting brokerage, but investor characteristics remain important, with, for example, both institutional sellers and foreign buyers being positively related to broker use. However, institutional investors in New York are less associated with double brokerage than non-institutional investors. This is in contrast to London, where institutional investors are more associated with double brokerage. Variable brokerage costs indicate important, persistent differences in the organization of real estate investment firms between markets in response to different institutional arrangements. The regression results illustrate such differences, but do not explain why broker use and costs vary between the two markets concerned.

New institutional economics postulates that what appears as market inefficiency (investors incurring higher transaction costs for reasons not related to asset qualities) is a reaction to market norms and the costs of enforcing rules and maintaining and transferring property rights. Institutional arrangements (Davis and North, 1971) arguably reflect the most efficient system of wealth maximization whilst "inefficient governance will be detected and undone" (Friedman, 1966). Thus, the institutional form that is observed should be that which mitigates the most risk at the least cost (Williamson 1991). For instance, the system of exchange in (http://centaur.reading.ac.uk/). Emerald does not grant permission for this article to be further copied/distributed or hosted elsewhere without the express permission from Emerald Group Publishing Limited. 
which both seller and buyer retain separate broker representation creates an environment well suited to the enforcement of norms and rules in an otherwise opaque market. On the other hand, if the market institutions current in London and New York City are not shaped solely by asset attributes then, as Allen (2012) notes, some aspects of the institutional environment, such as the culture of the market, must be driving the different institutional arrangements identified herein

The greater propensity for double brokerage in London may reflect transactional efficiencies from this approach that are not observable in the data available to this study. For example, future studies could provide valuable insights into the liquidity effects of different forms of brokerage. Nonetheless, a double brokered transaction provides an environment conducive to information capture and control by the brokers involved. This is a consequence of their privileged access to knowledge of the asset and the preferences of both investment principals. It creates a network structure defined by three distinct exchange relationships (tri-dyad form), a system through which neither party - buyer or seller - is privy to as much information about the deal (the asset and counterparty), as the intermediaries (brokers) that stand between them (Burt, 1992). So, while providing a mechanism to reduce 'opportunism' during the exchange (Williamson, 1979), a system of double brokerage paradoxically embeds strategically important market knowledge in the hands of intermediaries, away from seller and buyer. In turn, this makes adjustment away from such a system and the reduction of transaction costs more difficult.

This study has important implications for existing and future real estate research. Holding periods within commercial real estate portfolios are affected by transaction costs and these, in turn, affect trading volumes, risk and asset pricing (Collett et al., 2003). This study offers sui (http://centaur.reading.ac.uk/). Emerald does not grant permission for this article to be further copied/distributed or hosted elsewhere without the express permission from Emerald Group Publishing Limited. 
generis insight into the dynamic nature of transaction costs across ostensibly similar investment markets. Unlike previous work, it provides evidence of market specific transaction costs and concludes that variable costs are driven by subtle differences in market institutions (Allen, 2012). Future research that applies transaction costs to any manner of real estate inquiries must adjust the costs of the transaction to individual market realities.

\section{REFERENCES}

Alchian, A. and Demsetz, H. (1972), "Production, Information Costs, and Economic Organization", American Economic Review, Vol. 62 No. 5, pp. 772-795.

Allen, D. (2012), The Institutional Revolution, University of Chicago Press, Chicago.

Anglin, P.M. and Arnott, R. (1991), "Residential Real Estate Brokerage as a Principal-Agent Problem", The Journal of Real Estate Finance and Economics, Vol. 4 No. 2, pp. 99-125.

Bajtelsmit, V.L. and Worzala, E. M. (1997), "Adversarial Brokerage in Residential Real Estate Transactions: The Impact of Separate Buyer Representation", Journal of Real Estate Research, Vol. 14, pp. 65-75.

Bond, S., Hwang, S., Lin, Z. and Vandell, K. D. (2007), "Marketing Period Risk in a Portfolio Context: Theory and Empirical Estimates from the UK Commercial Real Estate Market”, The Journal of Real Estate Finance and Economics, Vol. 34 No. 4, pp. 447-461.

Burt, R. and Knez, M. (1995), "Kinds of Third-Party Effects on Trust", Rationality and Society, Vol. 7 No. 3, pp. 255-292.

Coase, R. (1960), “The Problem of Social Cost”, Journal of Law and Economics, Vol. 3, pp. $1-44$.

Coase, R. (1964), “Discussion”, The American Economic Review, Vol. 54, pp. 194-197.

Collett, D., Lizieri, C. and Ward, C. (2003), "Timing and the Holding Periods of Institutional Real Estate", Real Estate Economics, Vol. 31 No. 2, pp. 205-222.

Davis, L. and North, D. (1971), Institutional Change and American Economic Growth, University of Cambridge Press, Cambridge.

Elder, H. W., Zumpano, L. and Baryla, E. (2000), "Buyer Brokers: Do They Make a Difference? Their Influence on Selling Price and Search Duration", Real Estate Economics, Vol. 28 No. 2, pp. 337-362. 
Friedman, M. (1966), "The Methodology of Positive Economics", in Friedman, M. (Ed.), Essays in Positive Economics, University of Chicago Press, Chicago, pp. 3-16, 30-43.

Graff, R. and Webb, J. (1997), “Agency Costs and Inefficiency in Commercial Real Estate”, Journal of Real Estate Portfolio Management, Vol. 3 No. 1, pp. 19-36.

Grossman, S. J. and Miller, M. H. (1988), "Liquidity and Market Structure", The Journal of Finance, Vol. 43 No. 3, pp. 617-633.

Hardin, W., Johnson, K. and Zhonghua, W. (2009), "Brokerage Intermediation in the Commercial Property Market”, Journal of Real Estate Research, Vol. 31 No. 4, pp. 397-420.

Hayek, F. A. (1945), "The Use of Knowledge in Society", American Economic Review, Vol. 35 No. 4, pp. 519-30.

Jud, G. D. (1983), "Real Estate Brokers and the Market for Residential Housing", AREUEA Journal, Vol. 11 No. 1, pp. 69-82.

Jud, G. D. and Frew, J. (1986), "Real Estate Brokers, Housing Prices and the Demand for Housing”, Urban Studies, Vol. 23 No. 1, pp. 21-31.

Klein, P. (1996), "Economic Calculation and the Limits of Organization", The Review of Austrian Economics, Vol. 9 No. 2, pp. 51-77.

Lin, Z. and Vandell, K. D. (2007), "Illiquidity and Pricing Biases in the Real Estate Market", Real Estate Economics, Vol. 35 No. 3, pp. 291-330.

Lizieri, C. and N. Kutsch. Who Owns The City 2006: Office Ownership in the City of London, Development Securities Plc and The University of Reading, London, 2006.

MacKinnon, G. H. and Al Zaman, A. (2009), "Real Estate for the Long Term: The Effect of Return Predictability on Long-Horizon Allocations", Real Estate Economics, Vol. 37 No. 1, pp. 117-153.

Malone, T. W. and Smith, S. A. (1988), "Modelling the Performance of Organizational Structures”, Operations Research, Vol. 36 No. 3, pp. 421-436.

McAllister, P., Hughes, C. and Gallimore, P. (2008), "Principal-Agent Issues in Asset Acquisition: UK Institutions and their Investment Agents", Journal of Property Research, Vol. 25 No. 4, pp. 269-283.

Mises, L. V. (1949), Human Action, Yale University Press, New Haven.

Newell, G., Adair, A. and McGreal, S. (2010), "Robustness of capital flows into the European commercial property markets during the global financial crisis", Journal of European Real Estate Research, Vol. 3 No. 3, pp.182-202. 
Rehring, C. (2012), "Real Estate in a Mixed-Asset Portfolio: The Role of the Investment Horizon", Real Estate Economics, Vol. 40 No. 1, pp. 65-95.

Rutherford, R.C., Springer, T. M. and Yavas, A. (2005), "Conflicts Between Principals and Agents: Evidence from Residential Brokerage", Journal of Financial Economics, Vol. 76 No. 3, pp. 627-665.

Salant, S. W. (1991), "For Sale By Owner: When to Use a Broker and How to Price the House", Journal of Real Estate Finance and Economics, Vol. 4 No. 2, pp. 157-173.

Sawyer, S., Crowston, K., Wigand, R. and Allbritton, M. (2003), "The Social Embeddedness of Transactions: Evidence from the Residential Real-Estate Industry", The Information Society, Vol. 19 No. 2, pp. 135-154.

Scofield, D. (2013), "Time to completion liquidity in UK commercial real estate investment: 2000-2008”, Journal of European Real Estate Research, Vol. 6 No. 1, pp. 34-47.

Wiley, J. A., Waller, B. and Brastow, R. (2013), "Two sides of dual agency: evidence from homebuyers and transactions", Journal of Property Research, Vol. 30 No. 1, pp. 47-66.

Williamson, O. E. (1979), "Transaction-Cost Economics: The Governance of Contractual Relations", The Journal of Law and Economics, Vol. 22 No. 2, pp. 233-261.

Williamson, O. E. (1991), "Comparative Economic Organization: The Analysis of Discrete Structural Alternatives”, Administrative Science Quarterly, Vol. 36 No. 2, pp. 269-296

Williamson, O. E. (2008), "Outsourcing: Transaction Cost Economics and Supply Chain Management”, Journal of Supply Chain Management, Vol. 44 No. 2, pp. 5-16.

Yavas, A. and Colwell, P. (1999), "Buyer Brokerage: Incentive and Efficiency Implications", Journal of Real Estate Finance and Economics, Vol. 18 No. 3, pp. 259-277.

Yinger, J. A. (1981), "Search Model of Real Estate Broker Behaviour", The American Economic Review, Vol. 71 No. 4, pp. 591-605.

Zenger, T.R., Felin, T. and Bigelow, L. S. (2011), "Theories of the Firm-Market Boundary", The Academy of Management Annals, Vol. 5 No. 1, pp. 89-133.

Zietz, E. M. and Sirmans, G. S. (2011), "Real Estate Brokerage Research in the New Millennium", Journal of Real Estate Literature, Vol. 19 No. 1, pp. 3-40.

Zumpano, L., Elder, H. and Baryla, E. (1996), "Buying a House and the Decision to Use a Real Estate Broker", Journal of Real Estate Finance and Economics, Vol. 13 No. 2, pp. 169181. 
TABLES

Table 1: Patterns in brokerage - metro level

\begin{tabular}{|c|c|c|c|c|c|c|c|}
\hline & No broker & $\begin{array}{l}\text { For seller } \\
\text { only }\end{array}$ & $\begin{array}{c}\text { For buyer } \\
\text { only }\end{array}$ & $\begin{array}{l}\text { Broker for } \\
\text { both }\end{array}$ & Total & $\begin{array}{c}\text { Seller } \\
\text { represented }\end{array}$ & $\begin{array}{c}\text { Buyer } \\
\text { represented }\end{array}$ \\
\hline \multicolumn{8}{|c|}{ Number of transactions } \\
\hline London & 460 & 782 & 389 & 1,754 & 3,385 & 2,536 & 2,143 \\
\hline New York & 3,398 & 2,011 & 54 & 490 & 5,953 & 2,501 & 544 \\
\hline \multicolumn{8}{|c|}{ Percentage by number } \\
\hline London & 14 & 23 & 11 & 52 & 100 & 75 & 63 \\
\hline New York & 57 & 34 & 1 & 8 & 100 & 42 & 9 \\
\hline \multicolumn{8}{|l|}{ Value $(\$ b n)^{1}$} \\
\hline London & 34.4 & 48.5 & 22.7 & 117.6 & 223.2 & 166.1 & 140.3 \\
\hline New York & 55.6 & 101.9 & 4.0 & 15.7 & 177.2 & 117.6 & 19.7 \\
\hline \multicolumn{8}{|c|}{ Percentage by value ${ }^{2}$} \\
\hline London & 15 & 22 & 10 & 53 & 100 & 75 & 63 \\
\hline New York & 31 & 57 & 2 & 9 & 100 & 66 & 11 \\
\hline
\end{tabular}


Table 2: Patterns in brokerage by sector

\begin{tabular}{|c|c|c|c|c|c|c|c|}
\hline & No broker & $\begin{array}{l}\text { For seller } \\
\text { only }\end{array}$ & $\begin{array}{l}\text { For buyer } \\
\text { only }\end{array}$ & $\begin{array}{l}\text { Broker for } \\
\text { both }\end{array}$ & Total & $\begin{array}{c}\text { Seller } \\
\text { represented }\end{array}$ & $\begin{array}{c}\text { Buyer } \\
\text { represented }\end{array}$ \\
\hline \multicolumn{8}{|c|}{$\%$ by number - London } \\
\hline Apartment & 35 & 27 & 14 & 24 & 100 & 51 & 37 \\
\hline Hotel & 44 & 34 & 6 & 17 & 100 & 50 & 22 \\
\hline Industrial & 14 & 24 & 14 & 48 & 100 & 73 & 62 \\
\hline Office & 12 & 23 & 11 & 53 & 100 & 76 & 64 \\
\hline Retail & 11 & 19 & 13 & 57 & 100 & 77 & 70 \\
\hline \multicolumn{8}{|c|}{$\%$ by number - New York } \\
\hline Apartment & 59 & 32 & 1 & 8 & 100 & 40 & 9 \\
\hline Hotel & 65 & 29 & 3 & 3 & 100 & 32 & 6 \\
\hline Industrial & 73 & 21 & 1 & 6 & 100 & 27 & 6 \\
\hline Office & 39 & 49 & 1 & 11 & 100 & 60 & 12 \\
\hline Retail & 62 & 30 & 1 & 7 & 100 & 37 & 8 \\
\hline \multicolumn{8}{|c|}{$\%$ by value - London } \\
\hline Apartment & 53 & 27 & 5 & 15 & 100 & 42 & 21 \\
\hline Hotel & 42 & 31 & 8 & 19 & 100 & 50 & 27 \\
\hline Industrial & 16 & 21 & 13 & 51 & 100 & 71 & 64 \\
\hline Office & 12 & 23 & 10 & 56 & 100 & 79 & 66 \\
\hline Retail & 23 & 14 & 13 & 50 & 100 & 65 & 63 \\
\hline \multicolumn{8}{|c|}{$\%$ by value - New York } \\
\hline Apartment & 42 & 46 & 2 & 9 & 100 & 56 & 12 \\
\hline Hotel & 49 & 39 & 4 & 8 & 100 & 47 & 12 \\
\hline Industrial & 70 & 22 & 1 & 7 & 100 & 30 & 8 \\
\hline Office & 23 & 66 & 2 & 9 & 100 & 75 & 11 \\
\hline Retail & 50 & 39 & 6 & 5 & 100 & 44 & 11 \\
\hline $\begin{array}{l}\text { Sample size } \\
\text { For New Yo }\end{array}$ & $\begin{array}{l}\text { London } \\
\text { Apartmer }\end{array}$ & $\begin{array}{l}\text { rtments } \\
2,711, \mathrm{H}\end{array}$ & $\begin{array}{l}\text { Hotels } \\
s=147,1\end{array}$ & 99, Indus & $\begin{array}{l}=250, \\
\text { Office }\end{array}$ & $\begin{array}{l}e=2,444 \\
10, \text { Retail }\end{array}$ & $\begin{array}{l}\text { ail = 531. } \\
042 .\end{array}$ \\
\hline
\end{tabular}


Table 3: Patterns in brokerage over time

\begin{tabular}{|c|c|c|c|c|c|c|c|}
\hline & No broker & $\begin{array}{l}\text { For seller } \\
\text { only }\end{array}$ & $\begin{array}{c}\text { For buyer } \\
\text { only }\end{array}$ & $\begin{array}{l}\text { Broker for } \\
\text { both }\end{array}$ & Total & $\begin{array}{l}\text { Seller } \\
\text { represented }\end{array}$ & $\begin{array}{l}\text { Buyer } \\
\text { represented }\end{array}$ \\
\hline \multicolumn{8}{|c|}{$\%$ by number - London } \\
\hline 2001-04 & 7 & 21 & 10 & 62 & 100 & 83 & 72 \\
\hline 2005-07 & 20 & 24 & 13 & 43 & 100 & 67 & 56 \\
\hline 2008-11 & 13 & 25 & 11 & 51 & 100 & 76 & 62 \\
\hline \multicolumn{8}{|c|}{$\%$ by number - New York } \\
\hline 2001-04 & 52 & 46 & 1 & 2 & 100 & 47 & 2 \\
\hline 2005-07 & 63 & 31 & 1 & 6 & 100 & 37 & 6 \\
\hline $2008-11$ & 51 & 34 & 2 & 14 & 100 & 48 & 16 \\
\hline \multicolumn{8}{|c|}{$\%$ by value - London } \\
\hline 2001-04 & 11 & 21 & 10 & 58 & 100 & 79 & 68 \\
\hline 2005-07 & 18 & 23 & 12 & 48 & 100 & 71 & 60 \\
\hline 2008-11 & 15 & 22 & 8 & 55 & 100 & 77 & 63 \\
\hline \multicolumn{8}{|c|}{$\%$ by value - New York } \\
\hline 2001-04 & 28 & 70 & 0 & 2 & 100 & 72 & 3 \\
\hline 2005-07 & 32 & 58 & 2 & 7 & 100 & 66 & 9 \\
\hline 2008-11 & 33 & 48 & 4 & 15 & 100 & 63 & 19 \\
\hline
\end{tabular}


Table 4: Form of brokerage by type and domicile of buyer

\begin{tabular}{|c|c|c|c|c|c|c|}
\hline & No broker & $\begin{array}{l}\text { For seller } \\
\text { only }\end{array}$ & $\begin{array}{l}\text { For buyer } \\
\text { only }\end{array}$ & $\begin{array}{l}\text { Broker for } \\
\text { both }\end{array}$ & Total & $\begin{array}{l}\text { Buyer } \\
\text { represented }\end{array}$ \\
\hline \multicolumn{7}{|c|}{$\%$ by number - London } \\
\hline Equity fund & 12 & 22 & 14 & 52 & 100 & 66 \\
\hline Institution & 10 & 16 & 13 & 60 & 100 & 73 \\
\hline Private & 15 & 26 & 11 & 48 & 100 & 58 \\
\hline Public & 23 & 17 & 13 & 46 & 100 & 59 \\
\hline User/Other & 12 & 36 & 9 & 43 & 100 & 52 \\
\hline Joint venture & 17 & 17 & 8 & 58 & 100 & 66 \\
\hline \multicolumn{7}{|c|}{$\%$ by number - New York } \\
\hline Equity fund & 59 & 35 & 2 & 5 & 100 & 6 \\
\hline Institution & 39 & 52 & 1 & 8 & 100 & 9 \\
\hline Private & 59 & 32 & 1 & 8 & 100 & 9 \\
\hline Public & 52 & 43 & 2 & 3 & 100 & 5 \\
\hline User/Other & 62 & 27 & 1 & 10 & 100 & 11 \\
\hline Joint venture & 29 & 57 & 2 & 12 & 100 & 14 \\
\hline \multicolumn{7}{|c|}{$\%$ by number - London } \\
\hline Domestic & 14 & 20 & 13 & 52 & 100 & 65 \\
\hline Part foreign & 13 & 19 & 7 & 61 & 100 & 68 \\
\hline Foreign & 12 & 21 & 11 & 56 & 100 & 67 \\
\hline Unknown & 14 & 38 & 7 & 41 & 100 & 49 \\
\hline \multicolumn{7}{|c|}{$\%$ by number - New York } \\
\hline Domestic & 59 & 32 & 1 & 8 & 100 & 8 \\
\hline Part foreign & 12 & 60 & 7 & 21 & 100 & 29 \\
\hline Foreign & 27 & 55 & 2 & 16 & 100 & 18 \\
\hline Unknown & 36 & 47 & 2 & 16 & 100 & 18 \\
\hline \multicolumn{7}{|c|}{$\begin{array}{l}\text { Samples for London: Equity fund }=250, \text { Institution }=1,087, \text { Private }=943, \text { Public }=281, \text { User } / \text { Other }= \\
576, \text { Joint venture }=248 . \text { Domestic }=1,785, \text { Part foreign }=115, \text { Foreign }=949, \text { Unknown domicile }=536\end{array}$} \\
\hline \multicolumn{7}{|c|}{$\begin{array}{l}\text { Samples for New York: Equity fund }=191, \text { Institution }=156, \text { Private }=4,202, \text { Public }=155, \text { User } / \text { Other }= \\
844, \text { Joint venture }=405 . \text { Domestic }=5,482, \text { Part foreign }=42, \text { Foreign }=129, \text { Unknown domicile }=300 .\end{array}$} \\
\hline
\end{tabular}


Table 5: Form of brokerage by type and domicile of seller

\begin{tabular}{|c|c|c|c|c|c|c|}
\hline & No broker & $\begin{array}{l}\text { For seller } \\
\text { only }\end{array}$ & $\begin{array}{l}\text { For buyer } \\
\text { only }\end{array}$ & $\begin{array}{l}\text { Broker for } \\
\text { both }\end{array}$ & Total & $\begin{array}{l}\text { Seller } \\
\text { represented }\end{array}$ \\
\hline \multicolumn{7}{|c|}{$\%$ by number - London } \\
\hline Equity fund & 19 & 24 & 11 & 46 & 100 & 70 \\
\hline Institution & 9 & 21 & 12 & 58 & 100 & 79 \\
\hline Private & 15 & 25 & 14 & 46 & 100 & 72 \\
\hline Public & 19 & 23 & 9 & 49 & 100 & 72 \\
\hline User/Other & 14 & 29 & 8 & 49 & 100 & 78 \\
\hline Joint venture & 16 & 20 & 8 & 56 & 100 & 76 \\
\hline \multicolumn{7}{|c|}{$\%$ by number - New York } \\
\hline Equity fund & 40 & 52 & 0 & 8 & 100 & 60 \\
\hline Institution & 33 & 59 & 0 & 8 & 100 & 67 \\
\hline Private & 60 & 30 & 1 & 8 & 100 & 39 \\
\hline Public & 43 & 51 & 1 & 5 & 100 & 56 \\
\hline User/Other & 58 & 33 & 1 & 8 & 100 & 41 \\
\hline Joint venture & 32 & 56 & 2 & 9 & 100 & 65 \\
\hline \multicolumn{7}{|c|}{$\%$ by number - London } \\
\hline Domestic & 13 & 23 & 12 & 51 & 100 & 75 \\
\hline Part foreign & 14 & 22 & 6 & 58 & 100 & 80 \\
\hline Foreign & 15 & 23 & 11 & 51 & 100 & 74 \\
\hline Unknown & 15 & 23 & 7 & 55 & 100 & 77 \\
\hline \multicolumn{7}{|c|}{$\%$ by number - New York } \\
\hline Domestic & 59 & 32 & 1 & 8 & 100 & 40 \\
\hline Part foreign & 26 & 61 & 4 & 9 & 100 & 70 \\
\hline Foreign & 36 & 53 & 0 & 11 & 100 & 64 \\
\hline Unknown & 51 & 41 & 0 & 8 & 100 & 48 \\
\hline \multicolumn{7}{|c|}{$\begin{array}{l}\text { Samples for London: Equity fund }=218, \text { Institution }=1,213, \text { Private }=1,005, \text { Public }=419, \text { User/Other }= \\
274 \text {, Joint venture }=256 . \text { Domestic }=2,282, \text { Part foreign }=109, \text { Foreign }=812, \text { Unknown domicile }=182 .\end{array}$} \\
\hline $\begin{array}{l}\text { Samples for } \mathrm{N} \\
841, \text { Joint vent }\end{array}$ & $\begin{array}{l}\text { uity fund = } \\
\text { omestic = }\end{array}$ & $\begin{array}{l}\text { 9, Institut } \\
\text { 51, Part fo }\end{array}$ & $\begin{array}{l}=157, \text { Pri } \\
\text { n }=46, \mathrm{~F}\end{array}$ & $\begin{array}{l}=4,404, \\
\mathrm{gn}=118,\end{array}$ & $=81$, & $\begin{array}{l}\text { er/Other }= \\
\text { cile }=638 .\end{array}$ \\
\hline
\end{tabular}


Table 6: Percentage of sample accounted for by particular characteristics

\begin{tabular}{|c|c|c|c|}
\hline & London & $\begin{array}{l}\text { New York } \\
\text { commercial }\end{array}$ & $\begin{array}{l}\text { New York } \\
\text { apartments }\end{array}$ \\
\hline Seller broker & 76 & 44 & 40 \\
\hline Buyer broker & 66 & 9 & 9 \\
\hline Broker for both parties & 55 & 8 & 8 \\
\hline Industrial sector & 7 & 24 & - \\
\hline Office sector & 78 & 42 & - \\
\hline Retail sector & 15 & 34 & - \\
\hline Top quartile for sector & 25 & 25 & 25 \\
\hline Bottom quartile for sector & 25 & 25 & 25 \\
\hline Partial interest & 2 & 4 & 0 \\
\hline Institutional buyer & 48 & 12 & 5 \\
\hline Institutional seller & 50 & 11 & 3 \\
\hline Multiple buyers & 9 & 9 & 4 \\
\hline Multiple sellers & 10 & 8 & 3 \\
\hline Domestic buyer & 53 & 89 & 95 \\
\hline Part foreign buyer ${ }^{1}$ & 4 & 1 & 0 \\
\hline Foreign buyer & 29 & 3 & 1 \\
\hline Nationality of buyer unknown & 14 & 7 & 4 \\
\hline Domestic seller & 66 & 83 & 91 \\
\hline Part foreign seller ${ }^{1}$ & 4 & 1 & 0 \\
\hline Foreign seller & 24 & 3 & 0 \\
\hline Nationality of seller unknown & 6 & 12 & 9 \\
\hline Year 2001 & 9 & 3 & 1 \\
\hline Year 2002 & 8 & 2 & 1 \\
\hline Year 2003 & 7 & 3 & 2 \\
\hline Year 2004 & 10 & 7 & 6 \\
\hline Year 2005 & 11 & 15 & 19 \\
\hline Year 2006 & 12 & 18 & 19 \\
\hline Year 2007 & 12 & 17 & 16 \\
\hline Year 2008 & 7 & 11 & 10 \\
\hline Year 2009 & 7 & 5 & 6 \\
\hline Year 2010 & 9 & 8 & 8 \\
\hline Year 2011 & 8 & 11 & 11 \\
\hline No of observations & 2,948 & 3,073 & 2,710 \\
\hline
\end{tabular}


Table 7: Probit regressions - incidence of seller brokerage

\begin{tabular}{|c|c|c|c|}
\hline & London & NY commercial & NY apartments \\
\hline Constant & -0.53 & $-4.27 * * *$ & $-2.68 * * *$ \\
\hline Ln Price & $0.06 * *$ & $0.29 * * *$ & $0.17 * * *$ \\
\hline \multicolumn{4}{|l|}{ Sector } \\
\hline Industrial & -0.13 & $-0.47 * * *$ & - \\
\hline Retail & -0.04 & $-0.25 * * *$ & - \\
\hline Top quartile & 0.09 & $-0.19 * * *$ & $0.14 * *$ \\
\hline Bottom quartile & -0.06 & -0.06 & $-0.19 * * *$ \\
\hline Partial interest & $-0.46 * *$ & $-1.09 * * *$ & - \\
\hline Institutional seller & 0.07 & $0.21 * *$ & $0.50 * * *$ \\
\hline Multiple sellers & 0.12 & 0.18 & -0.01 \\
\hline \multicolumn{4}{|l|}{ Seller domicile } \\
\hline Unknown & $0.28 * *$ & $0.34 * * *$ & 0.07 \\
\hline Foreign & -0.01 & 0.14 & 0.29 \\
\hline \multicolumn{4}{|l|}{ Year } \\
\hline 2001 & $0.38 * * *$ & $-0.42 * * *$ & $-0.59 * * *$ \\
\hline 2002 & $0.63 * * *$ & $-0.34 *$ & -0.20 \\
\hline 2003 & $0.42 * * *$ & $-0.44 * * *$ & -0.30 \\
\hline 2004 & $0.33 * * *$ & $-0.38 * * *$ & $-0.37 * * *$ \\
\hline 2005 & $0.32 * * *$ & $-0.48 * * *$ & $-0.68 * * *$ \\
\hline 2006 & $-0.39 * * *$ & $-0.44 * * *$ & $-0.31 * * *$ \\
\hline 2007 & $-0.19 *$ & $-0.20 * *$ & -0.10 \\
\hline 2008 & $0.40 * * *$ & $-0.29 * * *$ & 0.04 \\
\hline 2009 & $0.36 * * *$ & -0.16 & $-0.27 * *$ \\
\hline 2010 & 0.00 & 0.04 & 0.08 \\
\hline No of observations & 2,948 & 3,073 & 2,710 \\
\hline Wald $\chi^{2}$ & 159.44 & 398.10 & 202.91 \\
\hline Probability $>\chi^{2}$ & 0.00 & 0.00 & 0.00 \\
\hline Log likelihood & -2321.5 & -3071.2 & -2631.0 \\
\hline
\end{tabular}

Notes: $* * *, * *$ and $*$ denote $1 \%, 5 \%$ and $10 \%$ significance levels, respectively. The dependent variable equals 1 where a broker for the seller is observed and 0 otherwise. Omitted categories for dummy independent variables are office, seller not an institution, single seller, domestic seller, full ownership and year is 2011. The price variable has been instrumented as per discussion in the main text. 
Table 8: Probit regressions - incidence of buyer brokerage

\begin{tabular}{|c|c|c|c|}
\hline & London & NY commercial & NY apartments \\
\hline Constant & $1.37 * * *$ & $-1.57 * * *$ & $-2.53 * * *$ \\
\hline Ln Price & $-0.06 * *$ & 0.05 & $0.11 *$ \\
\hline \multicolumn{4}{|l|}{ Sector } \\
\hline Industrial & -0.08 & $-0.36 * * *$ & - \\
\hline Retail & $0.17 * *$ & $-0.31 * * *$ & - \\
\hline Top quartile & -0.06 & $-0.17 * *$ & 0.10 \\
\hline Bottom quartile & $-0.12 *$ & $-0.18 * *$ & $-0.20 *$ \\
\hline Partial interest & $-0.35 *$ & $-0.43 * *$ & - \\
\hline Institutional buyer & $0.30 * * *$ & $-0.41 * * *$ & -0.14 \\
\hline Multiple buyers & 0.02 & $0.32 * *$ & $0.32 *$ \\
\hline \multicolumn{4}{|l|}{ Buyer domicile } \\
\hline Unknown & $-0.32 * * *$ & $0.64 * * *$ & 0.21 \\
\hline Foreign & 0.09 & $0.47 * * *$ & 0.11 \\
\hline \multicolumn{4}{|l|}{ Year } \\
\hline 2001 & $0.28 * *$ & - & - \\
\hline 2002 & $0.29 * *$ & - & - \\
\hline 2003 & $0.29 * *$ & - & - \\
\hline 2004 & $0.30 * * *$ & - & - \\
\hline 2005 & $0.27 * *$ & $-0.56 * * *$ & $-1.00 * * *$ \\
\hline 2006 & $-0.52 * * *$ & $-0.54 * * *$ & $-0.89 * * *$ \\
\hline 2007 & $-0.22 * *$ & $-0.37 * * *$ & $-0.67 * * *$ \\
\hline 2008 & -0.04 & $-0.50 * * *$ & $-0.38 * * *$ \\
\hline 2009 & 0.09 & $-0.30 *$ & $-0.70 * * *$ \\
\hline 2010 & -0.08 & 0.14 & $0.36 * * *$ \\
\hline No of observations & 2,948 & 2,601 & 2,440 \\
\hline Wald $\chi^{2}$ & 214.93 & 147.26 & 190.73 \\
\hline Probability $>\chi^{2}$ & 0.00 & 0.00 & 0.00 \\
\hline Log likelihood & -2554.2 & -1838.2 & -1466.1 \\
\hline
\end{tabular}

Notes: $* * *, * *$ and $*$ denote $1 \%, 5 \%$ and $10 \%$ significance levels, respectively. The dependent variable equals 1 where a broker for the buyer is observed and 0 otherwise. Omitted categories for dummy independent variables are office, buyer not an institution, single buyer, domestic buyer, full ownership and year is 2011. The price variable has been instrumented as per discussion in the main text. 
Table 9: Probit regressions - incidence of broker representation for both parties

\begin{tabular}{|c|c|c|c|c|c|}
\hline & \multicolumn{2}{|l|}{ London } & NY commercial & \multicolumn{2}{|c|}{ NY apartments } \\
\hline Constant & -0.08 & & $-2.12 * * *$ & -1.83 & $* *$ \\
\hline Ln Price & 0.00 & & $0.09 * *$ & 0.05 & \\
\hline \multicolumn{6}{|l|}{ Sector } \\
\hline Industrial & -0.12 & & $-0.36 * * *$ & - & \\
\hline Retail & 0.11 & $*$ & $-0.29 * * *$ & - & \\
\hline Top quartile & -0.04 & & $-0.15 *$ & 0.16 & \\
\hline Bottom quartile & -0.10 & $*$ & $-0.18 *$ & -0.18 & $*$ \\
\hline Partial interest & -0.31 & & $-0.40 *$ & - & \\
\hline Institutional buyer & 0.23 & $* * *$ & $-0.38 * * *$ & -0.14 & \\
\hline Institutional seller & 0.13 & $* * *$ & $-0.38 * *$ & 0.06 & \\
\hline Multiple buyers & 0.15 & $*$ & $0.33 * *$ & 0.36 & $* *$ \\
\hline Multiple sellers & 0.07 & & -0.16 & 0.01 & \\
\hline \multicolumn{6}{|l|}{ Buyer domicile } \\
\hline Unknown & -0.20 & $* * *$ & $0.59 * * *$ & 0.26 & \\
\hline Foreign & 0.08 & & $0.48 * * *$ & 0.16 & \\
\hline \multicolumn{6}{|l|}{ Seller domicile } \\
\hline Unknown & 0.24 & $* *$ & 0.05 & 0.01 & \\
\hline Foreign & -0.04 & & 0.06 & 0.09 & \\
\hline \multicolumn{6}{|l|}{ Year } \\
\hline 2001 & 0.30 & $* * *$ & - & - & \\
\hline 2002 & 0.38 & $* * *$ & - & - & \\
\hline 2003 & 0.33 & $* * *$ & - & - & \\
\hline 2004 & 0.28 & $* *$ & - & - & - \\
\hline 2005 & 0.26 & $* *$ & $-0.52 * * *$ & -0.94 & $* * *$ \\
\hline 2006 & -0.56 & $* * *$ & $-0.59 * * *$ & -0.85 & $* * *$ \\
\hline 2007 & -0.25 & $* *$ & $-0.35 * * *$ & -0.60 & $* * *$ \\
\hline 2008 & 0.09 & & $-0.50 * * *$ & -0.31 & $* *$ \\
\hline 2009 & 0.10 & & $-0.41 * *$ & -0.62 & $* * *$ \\
\hline 2010 & -0.10 & & 0.15 & 0.41 & $* * *$ \\
\hline No of observations & 2,948 & & 2,601 & 2,440 & \\
\hline Wald $\chi^{2}$ & 218.38 & & 148.68 & 178.76 & \\
\hline Probability $>\chi^{2}$ & 0.00 & & 0.00 & 0.00 & \\
\hline Log likelihood & -2680.3 & & -1761.3 & -1426.0 & \\
\hline
\end{tabular}

Notes: $* * *, * *$ and $*$ denote $1 \%, 5 \%$ and $10 \%$ significance levels, respectively. The dependent variable equals 1 if there is a broker for each party and 0 otherwise. Omitted categories for dummy independent variables are office, buyer not an institution, seller not an institution, single buyer, single seller, domestic buyer, domestic seller, full ownership and year is 2011. The price variable has been instrumented as per discussion in the main text. 
Figure 1: Number of transactions in each location and wider market conditions

(a) London

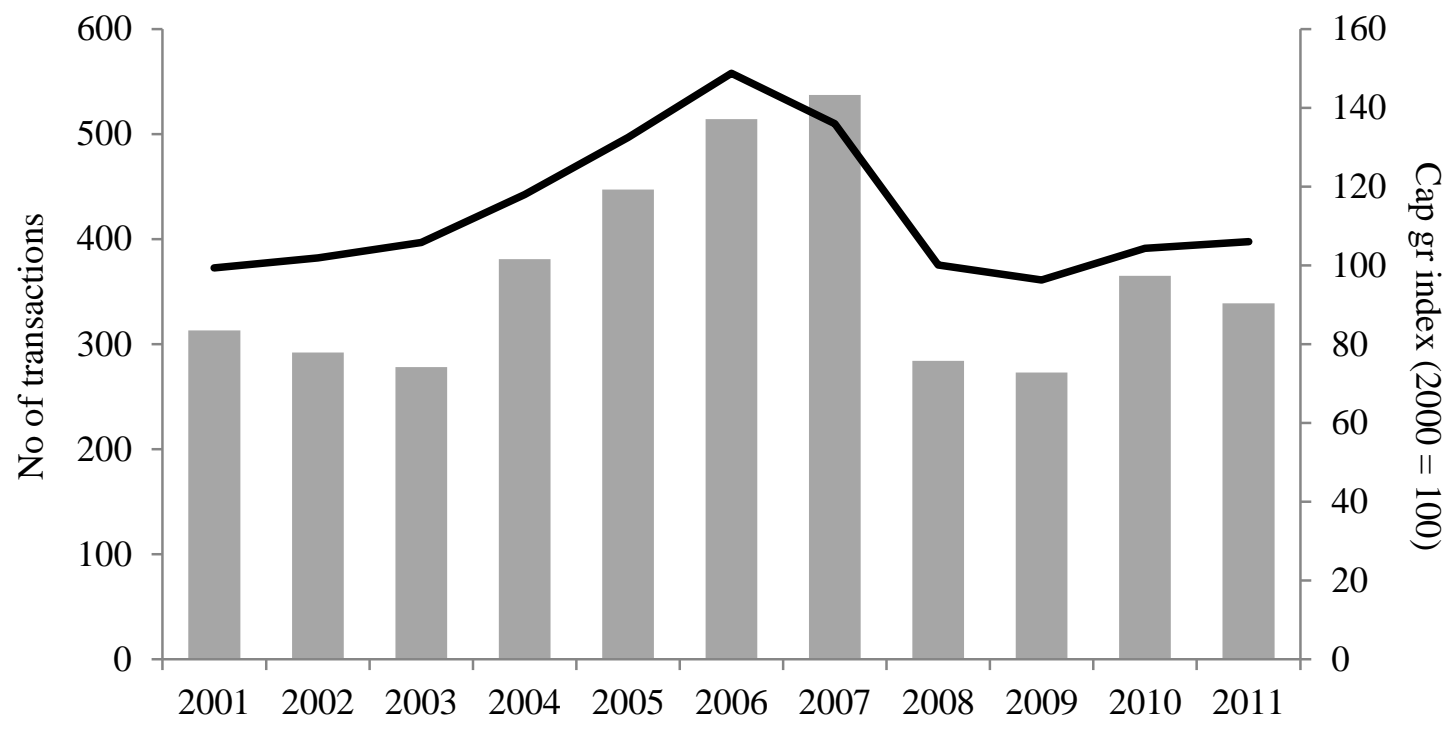

Transactions - Capital growth

(b) New York

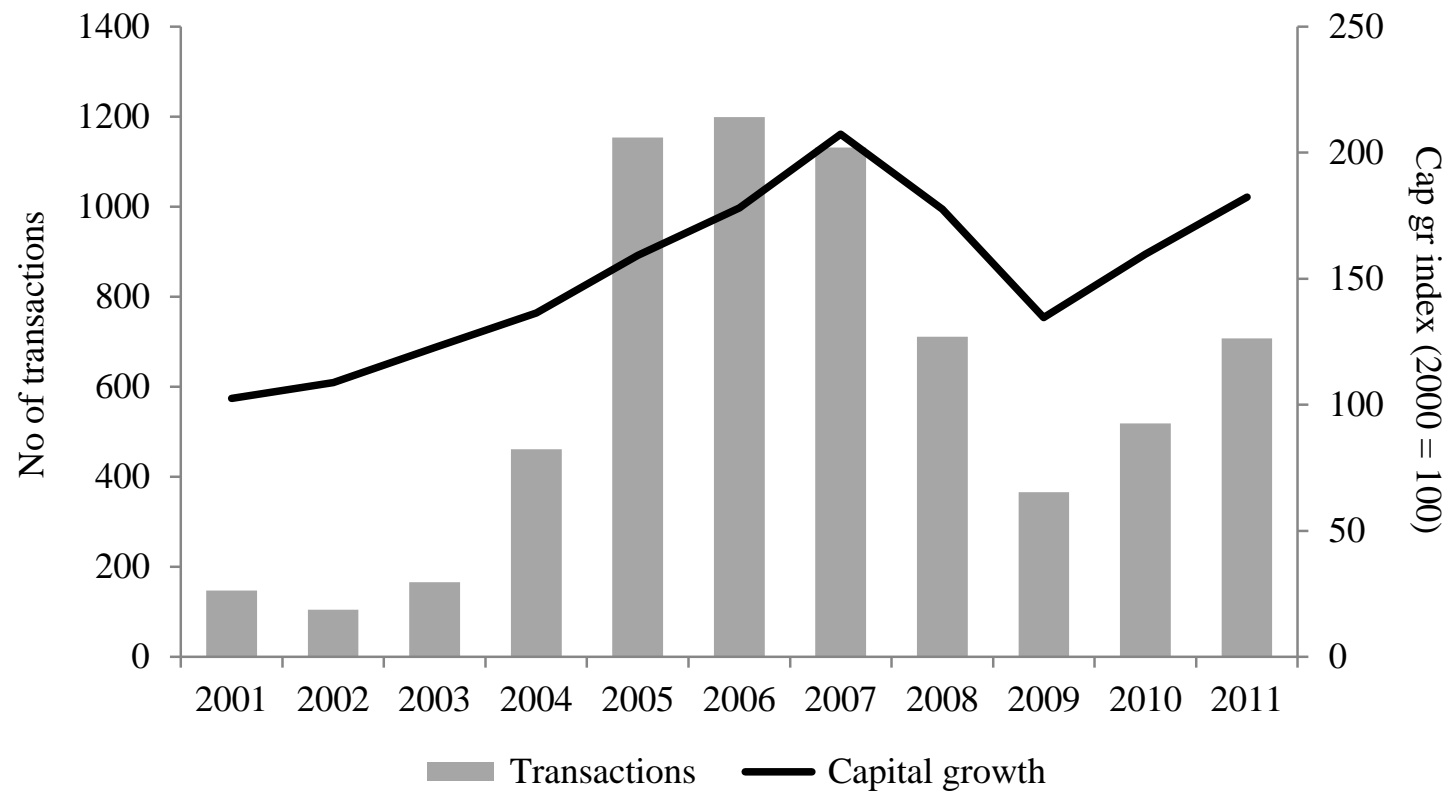

Notes: Transaction counts are from data supplied by RCA for this study. The capital growth index in (a) is the IPD UK quarterly index and in (b) is the Moody's/RCA CPPI for US Major Markets. In both cases, these are 'All Property' series. 


\section{Figure 2: Quality of asset and use of brokerage}

(a) London

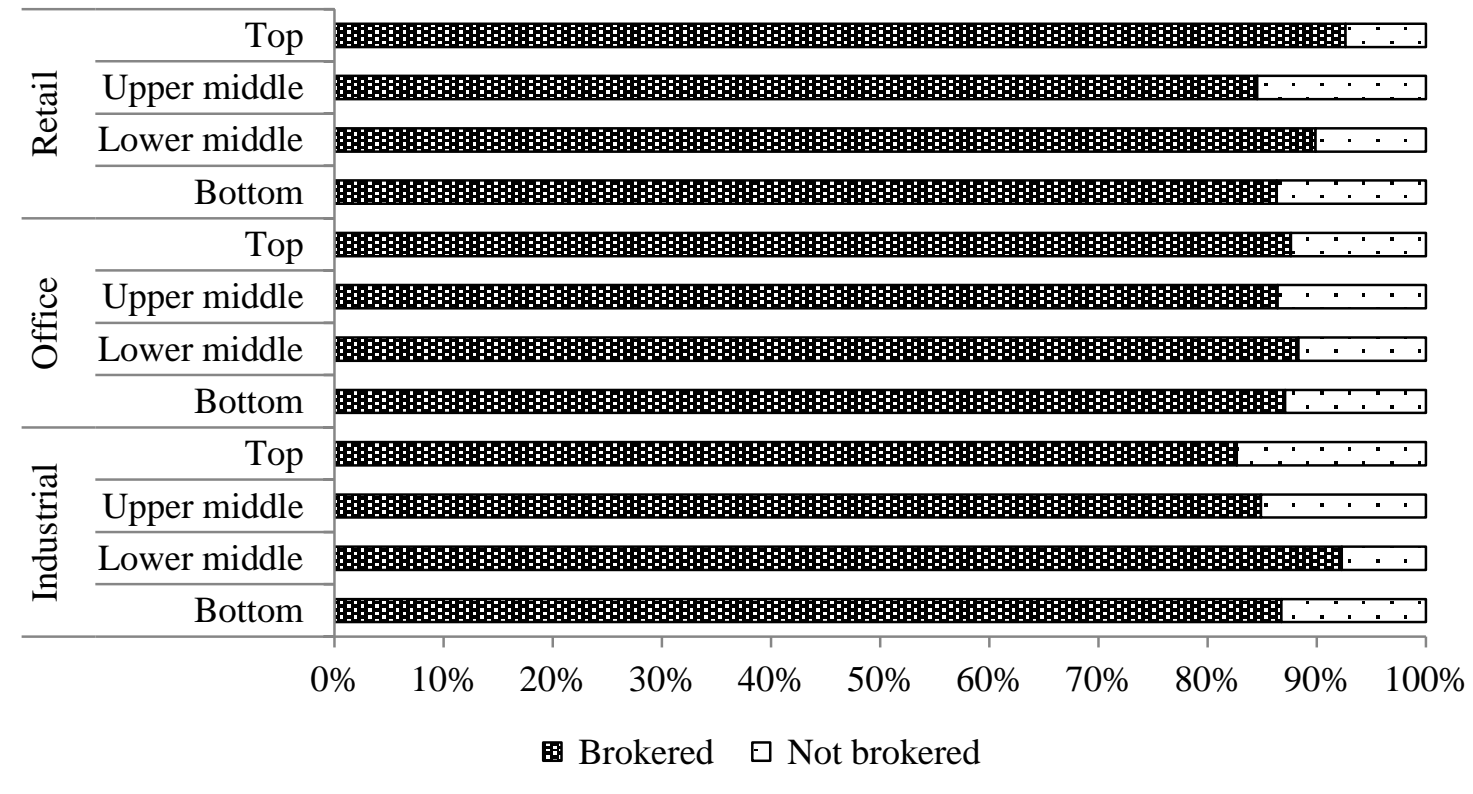

(b) New York

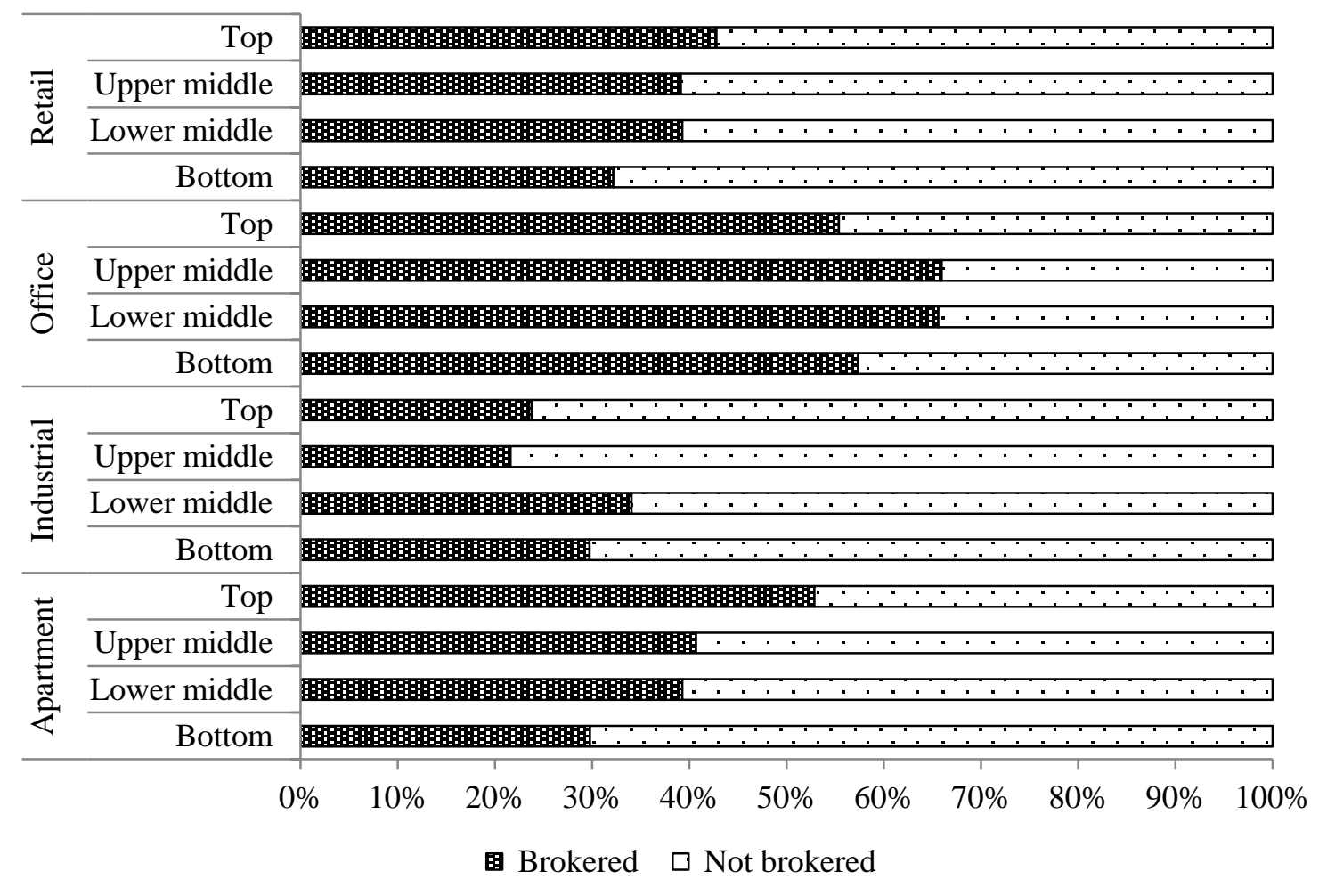

This article is (C) Emerald Group Publishing and permission has been granted for this version to appear here (http://centaur.reading.ac.uk/). Emerald does not grant permission for this article to be further copied/distributed or hosted elsewhere without the express permission from Emerald Group Publishing Limited. 